\title{
Tumor Necrosis Factor Receptor 2 Contributes to Ozone-induced Airway Hyperresponsiveness in Mice
}

\author{
STEPHANIE A. SHORE, IGOR N. SCHWARTZMAN, BRIAN LE BLANC, G. G. KRISHNA MURTHY, \\ and CLAIRE M. DOERSCHUK \\ Physiology Program, Harvard School of Public Health, Boston, Massachusetts
}

\begin{abstract}
The purpose of this study was to determine whether tumor necrosis factor (TNF) contributes to airway hyperresponsiveness (AHR) and migration of polymorphonuclear leukocytes (PMN) into the airways following exposure to ozone $\left(\mathrm{O}_{3}\right)$. Wild-type mice, TNF p55 or p75 receptor knockout mice (p55 TNFR -/- and p75 TNFR $-/-)$, as well as double receptor knockout mice (p55/p75 TNFR -/-), were exposed to $\mathrm{O}_{3}$. Three hours after cessation of $\mathrm{O}_{3}$, airway responses to inhaled methacholine were determined by whole body plethysmography using changes in enhanced pause (Penh) as an index of airway narrowing. In wild-type mice, $\mathrm{O}_{3}$ exposure $(0.5 \mathrm{ppm}$, $3 \mathrm{~h}$ ) caused a significant increase in airway responsiveness as indicated by a 1.2 log leftward shift in the methacholine doseresponse curve. In contrast, in p55/p75 TNFR - - mice, $\mathrm{O}_{3}$ caused only a $\mathbf{0 . 5}$ log shift in the dose-response curve $(p<0.05$ compared with wild-type). Similar results were obtained in p75 TNFR -/mice. In contrast, $\mathrm{O}_{3}$-induced airway hyperresponsiveness was not different in WT and p55 TNFR -/- mice. During $\mathrm{O}_{3}$ exposure $(1 \mathrm{pm}$, $3 \mathrm{~h}$ ), minute ventilation $\left(\dot{V}_{E}\right)$ decreased by $64 \pm 4 \%$ in wild-type, but only $24 \pm 5 \%$ in p55/p75 TNFR $-/-$ mice, indicating that despite their reduced $\mathrm{O}_{3}$-induced $\mathrm{AHR}$, the TNFR-deficient mice actually inhaled a greater dose of $\mathrm{O}_{3}$. Similar results were obtained in p75 - /- mice, whereas changes in $\dot{\mathrm{V}}_{\mathrm{E}}$ induced by $\mathrm{O}_{3}$ were the same in wild-type and p55 - /- mice. PMN numbers in bronchoalveolar lavage fluid recovered $21 \mathrm{~h}$ after cessation of exposure to $\mathrm{O}_{3}(2 \mathrm{ppm}, 3 \mathrm{~h})$ were significantly increased compared with after air exposure but were not different in wild-type and p55/p75 TNFR $-/-$ mice. Our results indicate that TNF contributes to the AHR but not the PMN emigration induced by acute $\mathrm{O}_{3}$ exposure.
\end{abstract}

Keywords: whole body plethysmography; polymorphonuclear leukocytes; minute ventilation; knockout mice; methacholine

Ozone $\left(\mathrm{O}_{3}\right)$ exposure causes damage to epithelial cells both in the airways and the alveoli. The response to this injury includes generation of numerous inflammatory mediators including cytokines and chemokines (1-4), an influx of polymorphonuclear leukocytes (PMN) (1,5-11), symptoms of respiratory irritation, and loss of lung function (11-14). In many species, including mice, acute exposure to $\mathrm{O}_{3}$ also causes airway hyperresponsiveness (1, 5-10). Airway hyperresponsiveness (AHR) is a defining feature of asthma, and hospital admissions for asthma increase on days of high $\mathrm{O}_{3}$ concentrations (15-17). $\mathrm{O}_{3}$-induced AHR and/or inflammation is likely to contribute to the ability of $\mathrm{O}_{3}$ to trigger episodes of asthma.

Data from many investigators suggest that $\mathrm{O}_{3}$-induced airway inflammation contributes to $\mathrm{O}_{3}$-induced AHR, but the precise component of inflammation required for AHR is still not firmly established. Early reports suggested that $\mathrm{O}_{3}$-induced

(Received in original form January 6, 2000 and in revised form January 25, 2001) This study was supported by the U.S. EPA and by HL33009, HL56383, HL52466, and ES00002.

Correspondence and requests for reprints should be addressed to Stephanie Shore, Ph.D., Physiology Program, Harvard School of Public Health, 665 Huntington Ave., Boston, MA 02115. E-mail: sshore@hsph.harvard.edu

Am J Respir Crit Care Med Vol 164. pp 602-607, 2001

Internet address: www.atsjournals.org migration of leukocytes into the airways was critical for the development of AHR $(8,10)$. However, more recent studies, including studies in mice, have not borne this out $(1,6,7,9)$. There is, however, reason to believe that tumor necrosis factor- $\alpha(\mathrm{TNF}-\alpha)$ may contribute to $\mathrm{O}_{3}$-induced AHR. First, synthesis of TNF- $\alpha$ is increased in alveolar macrophages and lung epithelial cells following $\mathrm{O}_{3}$ exposure of whole animals, and cultured macrophages or epithelial cells also express TNF- $\alpha$ in response to $\mathrm{O}_{3}(3,4,18)$. Second, genetic studies have identified a locus on mouse chromosome 17 that confers susceptibility to $\mathrm{O}_{3}$-induced inflammation. The TNF- $\alpha$ gene is close to this locus (19). Third, administration of TNF- $\alpha$ antibodies to rats prior to $\mathrm{O}_{3}$ exposure significantly attenuates other aspects of the response to $\mathrm{O}_{3}$ such as increases in macrophage adherence, in tracheal permeability, and in neutrophil migration (19-21). Finally, exogenous administration of TNF- $\alpha$ has been shown to cause AHR in humans and rats $(22,23)$.

The purpose of this study was to examine the role of TNF- $\alpha$ in $\mathrm{O}_{3}$-induced AHR. To that end, we measured the effect of $\mathrm{O}_{3}$ on airway responsiveness in wild-type mice and mice genetically deficient in either the p55, the p75, or both TNF receptors. Because it has been proposed that TNF- $\alpha$ contributes to $\mathrm{O}_{3}$-induced neutrophil influx into the airways (19), perhaps through effects on the expression of adhesion molecules (24), we also examined $\mathrm{O}_{3}$-induced influx of PMN into the airways in wild-type and TNF receptor-deficient mice.

\section{METHODS}

\section{Animals}

This study was approved by the Harvard Medical Area Standing Committee on Animals. Breeding pairs of mice genetically deficient in either the p55 or the p75 TNF receptor or both receptors were kindly provided by Dr. Jacques Peschon at Immunex (Seattle, WA) (25-27). The mice do not exert any overt phenotype when unchallenged, live a normal life-span, and breed normally. The mice have been backcrossed to a C57BL/6 background through six generations. Consequently, we used C57BL/6 mice as wild-types. Mice were studied at 7-9 wk of age. For measurements of $\mathrm{O}_{3}$-induced AHR, we used p55 - /- mice from Jackson Labs (28). These mice have also been backcrossed to a C57BL/6 background. The p55-deficient mice from Immunex and those from Jackson Labs were created using different targeting vectors. However, both mutations completely prevented the expression of $\mathrm{p} 55$.

\section{Protocol}

Three cohorts of mice were used in these studies. In the first cohort, airway responsiveness to inhaled aerosolized methacholine was assessed in each mouse on two occasions: once on the day before $\mathrm{O}_{3}$ exposure and then again $3 \mathrm{~h}$ after cessation of $\mathrm{O}_{3}$ exposure. $\mathrm{O}_{3}$ exposure was at $0.5 \mathrm{ppm}$ for $3 \mathrm{~h}$. In the second cohort, minute ventilation ( $\left.\dot{V}_{\mathrm{E}}\right)$ was measured during $\mathrm{O}_{3}$ exposure $(1 \mathrm{ppm}, 3 \mathrm{~h})$ in mice exposed in nose-only exposure plethysmographs. The purpose of these experiments was to determine whether differences in $\mathrm{O}_{3}$-induced AHR between wild-type and knockout animals were the result of differences in the inhaled dose of $\mathrm{O}_{3}$ resulting from differences in $\dot{V}_{E}$ during exposure. In the third cohort, mice were exposed to air or to $\mathrm{O}_{3}(2 \mathrm{ppm}$, $3 \mathrm{~h}) ; 21 \mathrm{~h}$ after cessation of exposure, the mice were killed by an over- 
dose of halothane and a bronchoalveolar lavage was performed. Blood was also obtained in these groups of mice, and blood PMN was assessed.

\section{Ozone Exposure}

Exposure to $\mathrm{O}_{3}$ or filtered room air was conducted in a stainless-steel chamber with a Plexiglas door on the front (approximately $145 \mathrm{~L}$ in volume). $\mathrm{O}_{3}$ was generated by passing dry $100 \%$ oxygen through ultraviolet light, and mixing it with filtered room air in the chamber. Chamber atmosphere was drawn continuously via a sampling port, and $\mathrm{O}_{3}$ concentration was measured by an $\mathrm{O}_{3}$ chemiluminescent analyzer (Model 49; Thermo Electron Instruments, Hopkinton, MA) which was calibrated by an ultraviolet photometric $\mathrm{O}_{3}$ calibrator (Model 49PS; Thermo Electron Instruments). Except for those mice in which measurements of $\dot{V}$ E during $\mathrm{O}_{3}$ exposure were made, during exposure, mice were placed in individual wire mesh cages within the chamber and were awake during exposure.

\section{Whole Body Plethysmography}

Mice were placed awake, unrestrained, and uninstrumented in a whole body plethysmograph (Buxco, Troy, NY). A constant bias flow was provided through the system in order to prevent buildup of $\mathrm{CO}_{2}$. As the mice breathe, pressure fluctuations in the plethysmograph are measured with reference to a similar chamber. These fluctuations represent differences between nasal flow and thoracic flow. With bronchoconstriction, there are changes in the shape of the pressure excursions particularly during expiration. These shape changes can be quantified by the algorithm for enhanced pause (Penh), described by others (29-31). The algorithm for Penh is

$$
\text { Penh }=\frac{\mathrm{Te}-\mathrm{Tr}}{\mathrm{Tr}} \times \frac{\mathrm{PEP}}{\mathrm{PIP}}
$$

$T_{E}$ is expiratory time. (Note that TE includes any end-expiratory pause or apnea that may occur.) PIP and PEP are peak inspiratory and peak expiratory pressures. The total area under the box pressure versus time curve during expiration is calculated, and the time required from the start of expiration to reach $64 \%$ of this area is determined (relaxation time, Tr). During methacholine challenge, Penh has been demonstrated empirically to correlate with pulmonary resistance (29-32), to be markedly reduced by bronchodilators, and is consequently believed to represent airway narrowing. Methacholineinduced changes in Penh are not substantively altered by tracheostomy and consequently are believed to represent changes in the lower airways, rather than the nose and pharynx $(30,33)$.

Dose-response curves to inhaled aerosolized methacholine were obtained as follows. Aerosols of saline and then of methacholine chloride dissolved in saline increasing in half $\log$ intervals from $1 \mathrm{mg} / \mathrm{ml}$ to $300 \mathrm{mg} / \mathrm{ml}$ were delivered to the chamber for $1 \mathrm{~min}$. Because the peak response to methacholine occurred between 3 and 7 min after the exposure, the average Penh value obtained over this time interval was used to measure the response to methacholine. Ten minutes were allowed to elapse between aerosol administrations. Aerosols were generated from an acorn nebulizer at an airflow of $10 \mathrm{~L} / \mathrm{min}$ and introduced through a port at the top of the chamber.

\section{Measurement of Ventilation during $\mathrm{O}_{3}$ Exposure}

Although whole body plethysmography is useful in assessing Penh and inferring AHR, it is inaccurate for measurements of tidal volume in any situation in which there may be bronchospasm. Therefore, to measure ventilation during $\mathrm{O}_{3}$ exposure, mice were placed in a Plexiglas restraining tube that served as a head-out flow plethysmograph, as previously described (34). The tube was fitted with a rubber gasket designed to fit snugly around the animal's neck. Once the animal was in the tube, a large piston fitted with a rubber O-ring was moved into place behind it, restraining movement. Air displaced at the body surface as the animal breathed passed across a pneumotach attached to a differential pressure transducer. The front end of the tube was inserted into a port in the $\mathrm{O}_{3}$ exposure chamber, and the animals were exposed nose only. The flow signal from the pneumotach was fed to a personal computer and analyzed using software (Buxco) that allowed for breath-by-breath measurements of minute ventilation ( $\left.\dot{\mathrm{V}}_{\mathrm{E}}\right)$, tidal volume $(\mathrm{V})$, breathing frequency (f), and end-expiratory pause (EEP).

\section{Bronchoalveolar Lavage}

Mice were killed with an overdose of halothane. The trachea was cannulated with a tubing adaptor, and the lungs were lavaged twice with phosphate-buffered saline $(1 \mathrm{ml})$ instilled and then slowly withdrawn over $30 \mathrm{~s}$. The recovered BAL fluid was placed on ice until centrifuged at $1200 \mathrm{rpm}$ at $4^{\circ} \mathrm{C}$ for $10 \mathrm{~min}$. Cell pellets were resuspended in saline, and the total number of cells counted with a hemocytometer. Aliquots of cells were also centrifuged onto glass slides at $800 \mathrm{rpm}$ for 5 min (Cytospin2; Shandon, Sewickley, PA), air dried, and stained with Wright-Giemsa (Leukostat, Fisher Scientific, Pittsburgh, PA). Cell differentiation was determined by counting 300 cells under $400 \times$ magnification. Blood cells were counted in a hemocytometer and differential counts were performed on 200 cells from Leukostat-stained blood smears.

\section{Statistics}

Within a given group of animals, changes in Penh induced by methacholine pre- $\mathrm{O}_{3}$ and post- $\mathrm{O}_{3}$ were assessed by paired $t$ tests. The dose of methacholine required to cause an increase in Penh of 2 units above the baseline value $\left(\mathrm{EC}_{2} \mathrm{Penh}\right)$ was calculated by log-linear interpolation between the two doses bounding the point at which a 2 unit increase occurred. Differences in $\mathrm{EC}_{2}$ Penh and $\mathrm{BAL}$ and blood cells between wild-type and TNFR-deficient animals were assessed by unpaired $t$ tests.

\section{RESULTS}

Airway responsiveness to inhaled aerosolized methacholine was measured before and after exposure to $\mathrm{O}_{3}(0.5 \mathrm{ppm}$ for $3 \mathrm{~h})$ in wild-type mice and in mice genetically deficient in both the p55 and p75 TNFR. Prior to $\mathrm{O}_{3}$ exposure, there was no significant difference in airway responsiveness between wild-type mice and p55/p75 TNFR -/- mice, except at the very highest concentration of methacholine where the p55/p75 TNFR -/mice had a statistically greater response than wild types $(\mathrm{p}<$ 0.05). Exposure to $\mathrm{O}_{3}$ caused an increase in airway responsiveness to methacholine in wild-type mice as indicated by the leftward shift in the dose-response curve (Figure 1, left). $\mathrm{O}_{3}$ also caused a significant increase in airway responsiveness in p55/ p75 TNFR - /- mice (Figure 1, right), but the magnitude of the change induced by $\mathrm{O}_{3}$ was not as great. In particular, wildtype mice showed significant differences pre- and post- $\mathrm{O}_{3}$ at concentrations as low as $3 \mathrm{mg} / \mathrm{ml}$, whereas in the p55/75 TNFR $-/-$ mice, significant effects of $\mathrm{O}_{3}$ were not observed until a methacholine concentration of $10 \mathrm{mg} / \mathrm{ml}$. Even at that concentration, the magnitude of the change induced by $\mathrm{O}_{3}$ was significantly less than in the wild-type mice $(\mathrm{p}<0.05)$. Overall, $\mathrm{O}_{3}$ caused a 15-fold decrease in the concentration of methacholine required to cause an increase in Penh of 2 units $\left(\mathrm{EC}_{2}\right.$ Penh) in wild-type mice, but only a 5 -fold decrease in
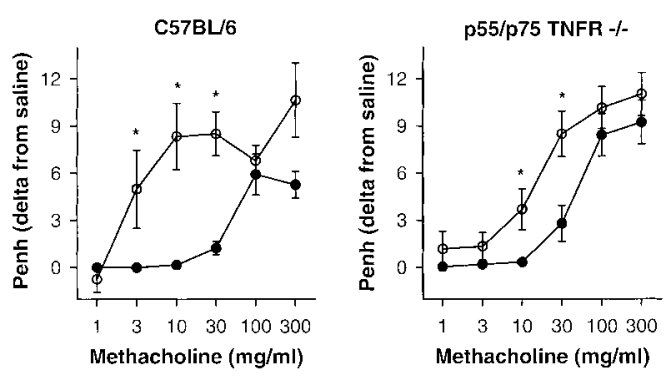

Figure 1. Changes in Penh (above saline values) induced by inhaled aerosolized methacholine prior to (closed symbols) and $3 \mathrm{~h}$ after cessation of exposure to $\mathrm{O}_{3}(0.5 \mathrm{ppm}, 3 \mathrm{~h}$ ) (open symbols) in wild-type (C57BL/6) mice (left) and double receptor-deficient (p55/p75 TNFR -/-) mice (right). Results are mean $\pm \mathrm{SE}$ of data from six mice in each group. ${ }^{*} \mathrm{p}<0.05$ compared with pre- $\mathrm{O}_{3}$. 

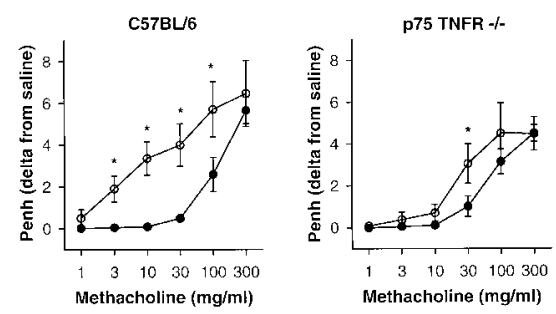

Figure 2. Changes in Penh (above saline values) induced by inhaled aerosolized methacholine prior to (closed symbols) and $3 \mathrm{~h}$ after cessation of exposure to $\mathrm{O}_{3}(0.5 \mathrm{ppm}, 3 \mathrm{~h}$ ) (open symbols) in wild-type (C57BL/6) mice (left) and p75 receptor-deficient (p75 TNFR -/-) mice (right). Results are mean \pm SE of data from six mice in each group. ${ }^{*} \mathrm{p}<$ 0.05 compared with pre- $\mathrm{O}_{3}$.

$\mathrm{EC}_{2}$ Penh in p55/p75 TNFR -/- mice. Similar results were obtained in $\mathrm{p} 5 \mathrm{TNFR}-/-$ mice (Figure 2 ). In contrast, $\mathrm{O}_{3}$-induced AHR was not reduced in p55 TNFR $-/-$ mice compared with wild-type control mice (Figure 3 ). Note that because the various groups of receptor-deficient animals were studied at different times, and because we observed differences in $\mathrm{O}_{3}$-induced AHR across cohorts of wild-type mice studied at different times, each group of mutant mice was compared with a cohort of wild-type mice exposed to $\mathrm{O}_{3}$ at the same time in the same exposure chambers.

The dose of $\mathrm{O}_{3}$ delivered to the lungs is the product of $\mathrm{O}_{3}$ concentration, exposure time, and $\mathrm{VE}_{\mathrm{E}}(35-37)$. To ensure that differences in $\mathrm{O}_{3}$-induced airway hyperresponsiveness between wild-type and knockout mice were not simply the result of differences in $\mathrm{O}_{3}$ dose arising from differences in $\dot{\mathrm{V}}_{\mathrm{E}}$, we measured $\dot{V}_{E}$ during $\mathrm{O}_{3}$ exposure in wild-type and TNF double receptor knockout mice (Figure 4). Prior to $\mathrm{O}_{3}$ exposure $\dot{\mathrm{V}}_{\mathrm{E}}$ averaged $2.8 \pm 0.21 \mathrm{ml} / \mathrm{min} / \mathrm{g}$ in wild-type and $2.5 \pm 0.21$ $\mathrm{ml} / \mathrm{min} / \mathrm{g}$ in $\mathrm{p} 55 / \mathrm{p} 75 \mathrm{TNFR}-/-$ mice (NS). In wild-type mice, $\mathrm{O}_{3}$ exposure caused a marked decrease in $\dot{V}_{\mathrm{E}}$. The decrease in $\dot{V}_{E}$ was significant $(p<0.01)$ within 30 min of the onset of $\mathrm{O}_{3}$ exposure and remained so throughout the remainder of the $\mathrm{O}_{3}$ exposure period. $\dot{V}_{E}$ also decreased significantly during $\mathrm{O}_{3}$ exposure of TNF double receptor knockout mice, but the magnitude of the response was much less. Overall, after $3 \mathrm{~h}$ of $\mathrm{O}_{3}$ exposure, $\dot{V}_{E}$ decreased by $64 \pm 4 \%$ in wild-type, but only $24 \pm$ $5 \%$ in TNF receptor-deficient mice $(\mathrm{p}<0.01)$. Thus, integrated over the 3-h exposure, the net inhaled dose of $\mathrm{O}_{3}$ was slightly greater in the TNF receptor-deficient mice. In wildtype mice, the decrease in $\dot{V}_{E}$ was the result of changes in both tidal volume $\left(\mathrm{V}_{\mathrm{T}}\right)$, which decreased $33 \pm 1 \%$ over the course of the $3 \mathrm{~h} \mathrm{O}_{3}$ exposure, and frequency, which decreased by
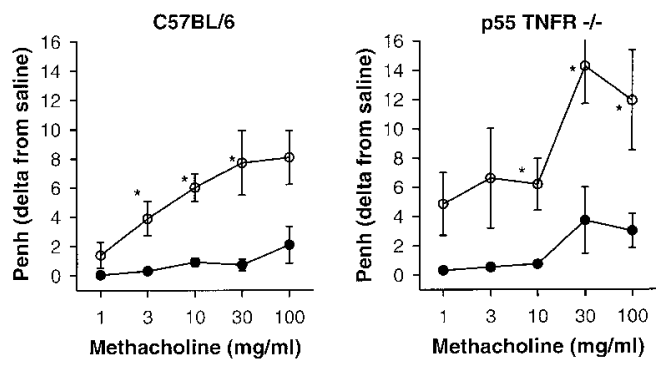

Figure 3. Changes in Penh (above saline values) induced by inhaled aerosolized methacholine prior to (closed symbols) and $3 \mathrm{~h}$ after cessation of exposure to $\mathrm{O}_{3}(0.5 \mathrm{ppm}, 3 \mathrm{~h}$ ) (open symbols) in wild-type (C57BL/6) mice (left) and p55 receptor-deficient (p55 TNFR -/-) mice (right) obtained from Jackson Labs (28). Results are mean \pm SE of data from four mice in each group. ${ }^{*} \mathrm{p}<0.05$ compared with pre- $\mathrm{O}_{3}$.

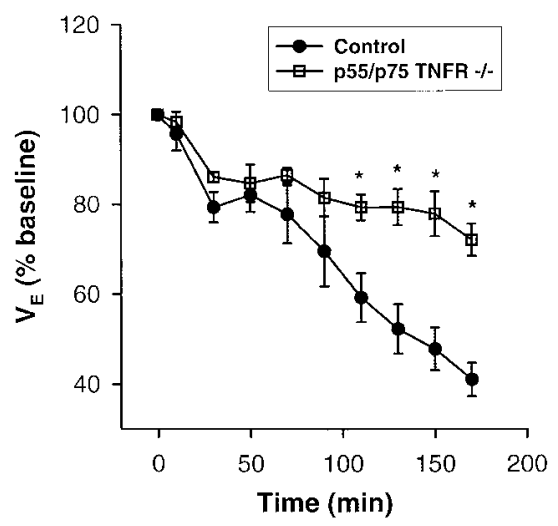

Figure 4. Changes in minute ventilation $\left(\mathrm{VE}_{\mathrm{E}}\right)$ during a 3-h $\mathrm{O}_{3}$ exposure (1 ppm) expressed as a percentage of baseline values measured in the 20-min period prior to initiation of exposure in wild-type mice and p55/ p75 TNFR -/- mice. Results are mean \pm SE of data from five mice in each group. ${ }^{*} p<0.05$ compared with wild type.

about $40 \pm 5 \%$. In wild-type mice, the change in breathing frequency during $\mathrm{O}_{3}$ exposure was largely the result of the addition of a pause at the end of expiration (Figure 5). In TNFR knockout mice exposed to $\mathrm{O}_{3}$ at the same time, there was only a $10 \pm 7 \%$ decrease in tidal volume and an $18 \pm 8 \%$ decrease in breathing frequency ( $\mathrm{p}<0.05$ compared with wild types). Furthermore, $\mathrm{O}_{3}$ caused only minor changes in end-expiratory pause in these mice (Figure 5).

Similar experiments were performed in p55 $-/-$ and p75 $-/-$ mice (Figures 6 and 7). (Note that these mice were studied at a different time from the double receptor knockouts.) Because we observed differences in $\mathrm{O}_{3}$-induced changes in $\dot{\mathrm{V}}_{\mathrm{E}}$ across cohorts of wild-type mice studied at different times, each group of mutant mice was compared with wild-type mice that were exposed to $\mathrm{O}_{3}$ at the same time in the same exposure chambers. Baseline $\dot{V}_{\mathrm{E}}$ normalized for body weight was not different in wild-type, p55 $-/-$, or p75 $-/-$ mice $(2.39 \pm$ $0.14,2.54 \pm 0.13$, and $2.26 \pm 0.11 \mathrm{ml} / \mathrm{min} / \mathrm{g}$, respectively). Three hours of exposure to $\mathrm{O}_{3}(1 \mathrm{ppm})$ (Figure 6) caused a substantive and significant decrease in $\dot{V}_{E}$ that was not different in wildtype and p55 -/- mice. However, in p75 -/- mice, $3 \mathrm{~h}$ exposure to $\mathrm{O}_{3}$ failed to cause any significant change in $\dot{\mathrm{V}}_{\mathrm{E}}$. Thus, the effect on $\mathrm{O}_{3}$-induced changes in $\dot{\mathrm{V}}_{\mathrm{E}}$ observed in the double receptor knockout mice (Figure 4 ) is primarily caused by the absence of the p75 rather than the p55 receptor. Compared to wild types, the change in EEP induced by $\mathrm{O}_{3}$ was significantly reduced in both p $75-/-$ and p $55-/-$ mice (Figure 7 ).

In initial experiments in C57BL/6 mice, we did not observe an increase in BAL PMN at either 3 or $21 \mathrm{~h}$ after exposure to $0.5 \mathrm{ppm} \mathrm{O}_{3}$, but we did see an increase in PMN by $21 \mathrm{~h}$ but not $3 \mathrm{~h}$ after exposure to $2 \mathrm{ppm} \mathrm{O}_{3}$. Consequently, comparisons of BAL PMN between wild-type and TNF receptor knockout mice were performed with this latter exposure regimen. In air-

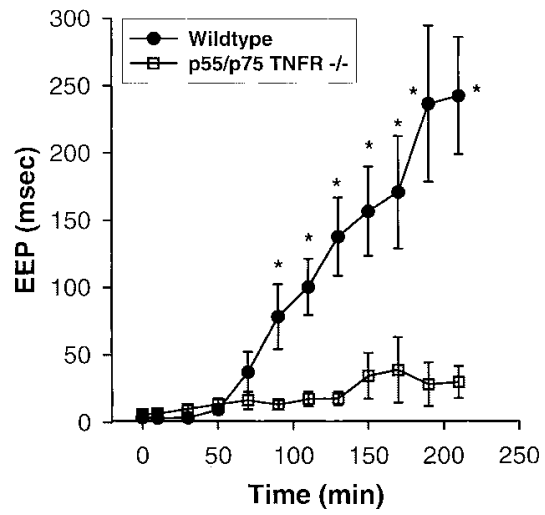

Figure 5. End-expiratory pause (EEP) measured during a 3-h $\mathrm{O}_{3}$ exposure (1 ppm) in wild-type and p55/p75 TNFR - /mice. Results are mean \pm SE of data from five mice in each group. $\mathrm{O}_{3}$ exposure was terminated at $\mathrm{t}=180$ min. ${ }^{*} \mathrm{p}<0.05$ compared with p55/p75 TNFR $-/-$. 


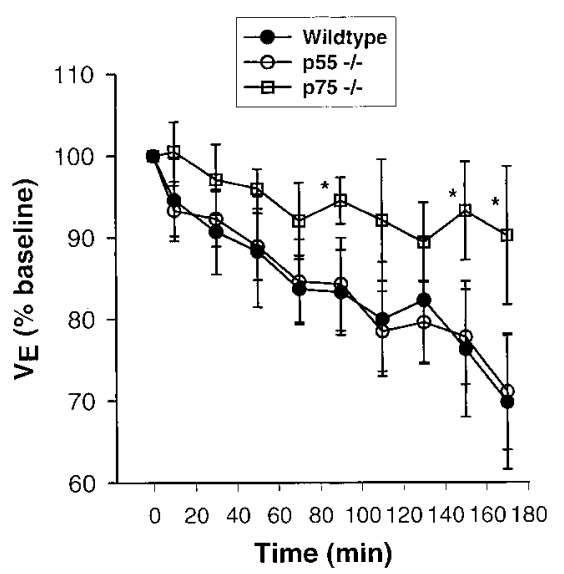

exposed mice, there was no difference in either total BAL cells or in BAL PMN between wild-type mice and mice deficient in both TNF receptors. PMN accounted for less than $1 \%$ of the total BAL cells (Figure 8, top panel). Surprisingly, $21 \mathrm{~h}$ after $\mathrm{O}_{3}$ exposure, total BAL cells were actually higher $(\mathrm{p}<$ 0.05 ) in TNF receptor-deficient mice than in wild types (Figure 8 , lower panel). Numbers of PMN were not different between the groups, nor was there any difference in the number of PMN expressed as a percentage of total cells in wild-type versus TNF receptor-deficient mice (33\% versus $29 \%$, respectively) although in both groups, PMN were markedly increased compared with air-exposed mice. To determine if differences in total BAL cells between wild-type and TNFRdeficient mice were due to differences in circulating leukocyte numbers, we also measured circulating total white blood cells $\left(2.6 \pm 0.5\right.$ versus $4.1 \pm 0.9$ cells $\times 10^{6} / \mathrm{ml}$ blood $)$ and total blood PMN $\left(0.46 \pm 0.05\right.$ and $0.57 \pm 0.15 \mathrm{PMN} \times 10^{6} / \mathrm{ml}$ blood) in wild-type and TNF double receptor knockout mice, respectively. The differences were not significant.

\section{DISCUSSION}

Our results indicate that $\mathrm{O}_{3}$-induced AHR is reduced in mice genetically deficient in TNF receptors. Taken together with data in the literature indicating that $\mathrm{O}_{3}$ induces TNF- $\alpha$ expression in alveolar macrophages and lung epithelial cells $(3,4$, 18 ), and that exogenous TNF- $\alpha$ is capable of inducing AHR in rats and humans $(22,23)$, these data support the hypothesis that TNF- $\alpha$ contributes to $\mathrm{O}_{3}$-induced AHR in mice. In contrast, we did not find any evidence for a role for TNF in the PMN migration induced by acute ( 2 ppm, $3 \mathrm{~h}) \mathrm{O}_{3}$ exposure: the numbers of PMN in the BAL were not significantly different in wild type compared to p55/p75 TNFR - /- mice.

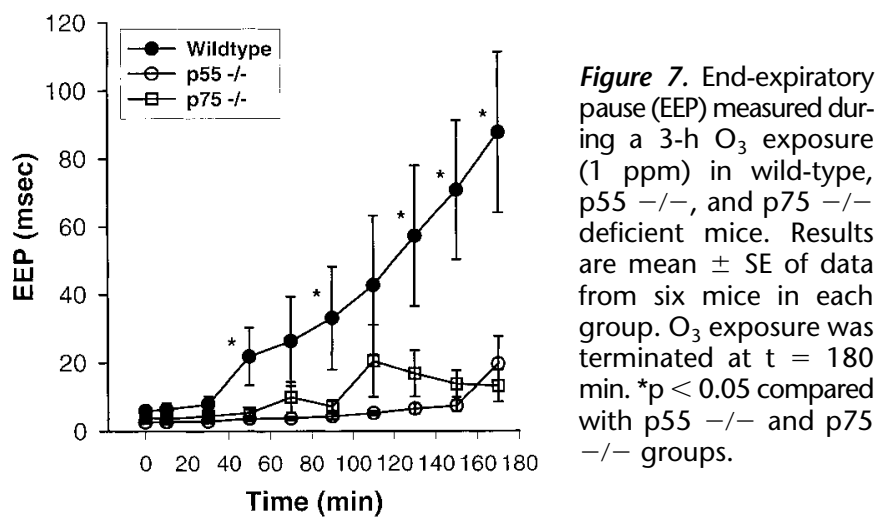

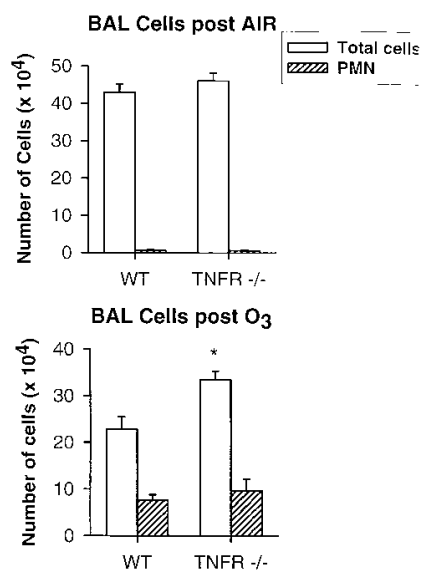

Figure 8. Bronchoalveolar lavage (BAL) cells harvested from wild-type and $\mathrm{p} 55 / 75$ TNFR $-/-$ mice after air exposure (top panel) or $21 \mathrm{~h}$ after cessation of exposure to $\mathrm{O}_{3}$ (2 ppm, $3 \mathrm{~h}$ ) (lower panel). Results are mean \pm SE of data from five or six mice in each group. ${ }^{*} \mathrm{p}<$ 0.05 compared with wild type.
In contrast to the results presented here (Figure 8), Kleeberger and colleagues (19) reported that a TNF- $\alpha$ antibody significantly reduces PMN migration induced by a longer term $\mathrm{O}_{3}$ exposure $(0.3 \mathrm{ppm}, 48 \mathrm{~h})$, data consistent with the results of genetic studies that identify a locus on mouse chromosome 17 close to the TNF- $\alpha$ gene that confers susceptibility to $\mathrm{O}_{3}$-induced inflammation. A preliminary report by the same group indicates that BAL PMN are also reduced in p55 and p75 TNFR -/- compared to wild-type mice following the same type of $\mathrm{O}_{3}$ exposure $(0.3 \mathrm{ppm}, 48 \mathrm{~h})$ (38). The most likely explanation for the difference between the results of Kleeberger and colleagues and those reported here, which indicate no role for TNF in $\mathrm{O}_{3}$-induced PMN migration, is the nature of the $\mathrm{O}_{3}$ exposure $(0.3 \mathrm{ppm}$ for $48 \mathrm{~h}$ versus $2 \mathrm{ppm}$ for $3 \mathrm{~h})$. In support of this argument, Young and coworkers (20) showed no effect of an anti-TNF antibody on PMN influx into BAL fluid when rats were exposed acutely to $\mathrm{O}_{3}(0.8 \mathrm{ppm}, 3 \mathrm{~h})$. Taken together, the data suggest a different mechanistic basis for the PMN migration induced by acute and more long term $\mathrm{O}_{3}$ exposure or by exposures to low versus higher $\mathrm{O}_{3}$ concentrations. In particular, TNF appears to be important following longer term exposure to low $\mathrm{O}_{3}$ concentrations, whereas other factors are important during acute exposure to higher concentrations. Other potential candidates are PAF and the chemokines CINC and MIP-1, each of which have been postulated to be important in PMN migration following acute exposure to $\mathrm{O}_{3}$ in rats or mice $(1,2,39)$. Differences in the mechanism of PMN migration induced by acute compared to the longer term $\mathrm{O}_{3}$ exposure are consistent with other observations of Kleeberger and coworkers who reported that the genetic factors that confer susceptibility to PMN migration under the two exposure conditions are not necessarily the same (40).

The biological activities of TNF are mediated by its binding to two structurally related, but functionally distinct receptors: TNFR1 or p55 and TNFR2 or p75. Based on the fact that the majority of TNF-dependent inflammatory functions have been ascribed to p55 (26), we expected to find that the p55 TNFR was the receptor important for $\mathrm{O}_{3}$-induced AHR. Instead, our results indicated reduced $\mathrm{O}_{3}$-induced AHR in p75 $-/-$ but not in p55 - /- mice (Figures 2 and 3 ). Similarly, the ventilatory response to $\mathrm{O}_{3}$ was reduced in $\mathrm{p} 75-/-$ but not in p55 - / - mice (Figures 4 and 6). Such findings are not without precedent, as p75 has also been shown to mediate some TNF effects (41-45), as well as to share others with p55 (27). For example, p75 -/- mice but not p55 $-/-$ mice are protected from experimental cerebral malaria, perhaps as a result of p75-dependent ICAM-1 upregulation by TNF- $\alpha$ in cerebral microvessels (44). The p75, but not the p55 TNF receptor also 
appears to be important in the migration of epidermal Langerhans cells (43). p75 is also the dominant TNFR on T cells, and mediates apoptosis of T cells in response to TNF (41).

We do not know exactly how TNF acts to induce AHR following $\mathrm{O}_{3}$ exposure. $\mathrm{O}_{3}$ causes epithelial cell damage, and $\mathrm{O}_{3}$-induced changes in tracheal permeability have been shown to be attenuated by anti-TNF- $\alpha$ antibodies (20). It is possible that these changes contribute to AHR by increasing the flux of inhaled methacholine across the epithelial barrier (20). Although TNF has been shown to act directly on airway smooth muscle cells and increase their influx of calcium in response to contractile agonists, we believe that such an action of TNF is unlikely to contribute to the effects described here as it is mediated by p55 and not p75 receptors (46), whereas the role of TNF in $\mathrm{O}_{3}$-induced AHR appears to involve p75 (Figure 2) but not p55 (Figure 3).

The inhaled dose of $\mathrm{O}_{3}$ is the product of $\mathrm{O}_{3}$ concentration, exposure time, and ventilation (35-37). Thus, differences in $\dot{V}_{E}$ between wild-type and TNFR-deficient mice during $\mathrm{O}_{3}$ exposure would result in differences in the inhaled dose of $\mathrm{O}_{3}$. To investigate the possibility that differences in the inhaled dose of $\mathrm{O}_{3}$ might account for differences in the ability of $\mathrm{O}_{3}$ to induce AHR in wild-type and TNFR-deficient mice, we measured $\dot{\mathrm{V}}_{\mathrm{E}}$ during $\mathrm{O}_{3}$ exposure in wild-type, p55 TNFR-/-, p75 TNFR $-/-$, and p55/p75 TNFR -/- mice. Our results indicate that $\mathrm{O}_{3}$ causes a substantive decrease in $\dot{\mathrm{V}} \mathrm{E}$ in wild-type and p $55-/-$ mice, but smaller decreases in $\dot{V}_{\mathrm{E}}$ in p $75-/-$ and p55/p75 - /- mice (Figures 4 and 6). The net effect of these differences is that the p $75-/-$ and p55/p $75-/-$ mice actually received a greater inhaled dose of $\mathrm{O}_{3}$ than the wild-type mice. Although the inhaled dose of $\mathrm{O}_{3}$ and the dose delivered to the tissues might not necessarily be the same, these results suggest that differences in dose are likely not responsible for differences in $\mathrm{O}_{3}$-induced AHR observed in these animals (Figures 1 and 2). However, it is possible that differences in $\dot{V}_{E}$ during $\mathrm{O}_{3}$ exposure might have influenced our PMN data. If $\mathrm{O}_{3}$-induced PMN migration does indeed require TNF, then the absence of any difference in BAL PMNs between p55/p75 TNF $-/-$ and wild-type mice (Figure 8 ) could be the result of the greater inhaled dose of $\mathrm{O}_{3}$ in the $\mathrm{p} 55 / \mathrm{p} 75$ TNFR -/- mice obscuring such an effect.

In rats, the decrease in $\dot{\mathrm{V}}_{\mathrm{E}}$ that occurs during $\mathrm{O}_{3}$ exposure (34) appears to be driven by a decrease in metabolic rate, as oxygen consumption and heart rate decrease $(47,48)$, but arterial $\mathrm{PCO}_{2}$ is relatively unchanged with $\mathrm{O}_{3}(49)$. It is likely that this decrease in metabolic rate arises at least in part from a regulated decrease in core body temperature, because the latter decreases $2-3^{\circ} \mathrm{C}$ during $\mathrm{O}_{3}$ exposure in rats (47), and as much as $6^{\circ} \mathrm{C}$ during $\mathrm{O}_{3}$ exposure in $\mathrm{C} 57 \mathrm{BL} / 6$ mice (50). Our results, which indicate a greater decrease in $\dot{\mathrm{V}} \mathrm{E}$ during $\mathrm{O}_{3}$ exposure in wild-type than in p55/p75 TNFR -/- or p75 -/mice, are consistent with the hypothesis that TNF accounts for at least part of the $\mathrm{O}_{3}$-induced decrease in metabolism. These results are consistent with the observations of other investigators (25) who demonstrated that TNF is a cryogenic or antipyretic factor and acts to attenuate LPS-induced fever. Alternatively, there may be less airway injury in TNFR-deficient mice, resulting in reduced formation of other mediators involved in these metabolic events. The role of TNF in these events is likely to be mediated through the p75 TNF receptor, since $\mathrm{O}_{3}$-induced changes in $\dot{\mathrm{V}}_{\mathrm{E}}$ were reduced in p75 TNFR $-/-$ (Figure 4 ) but not in p55 TNFR $-/-$ mice (Figure 6 ). It is also likely that the changes in EEP induced by $\mathrm{O}_{3}$ have a different mechanistic basis than the changes in $\dot{V}_{E}$ induced by $\mathrm{O}_{3}$, because changes in EEP were significantly attenuated in both p75 -/- and p55 -/- mice (Figure 7), whereas the changes in $\dot{V}$ E were only attenuated in p75 -/- mice (Figure 6).
In summary, our results indicate that at the $\mathrm{O}_{3}$ concentrations examined, TNF is important for the airway hyperresponsiveness, but not the PMN migration induced by acute $\mathrm{O}_{3}$ exposure in mice and that this effect of TNF appears to involve activation of the p75 TNFR. Whether TNF also contributes to exacerbations of asthma that occur during periods of high ambient ozone remains to be determined.

Acknowledgment: The TNFR deficient mice were kindly provided by Dr. Jacques Peschon at Immunex Corp., Seattle, WA. The authors would like to thank Dr. Joseph Mizgerd for assistance with breeding the mice.

\section{References}

1. Koto H, Salmon M, Haddad el B, Huang TJ, Zagorski J, Chung KF. Role of cytokine-induced neutrophil chemoattractant (CINC) in ozone-induced airway inflammation and hyperresponsiveness. Am J Respir Crit Care Med 1997;156:234-239.

2. Zhao Q, Simpson LG, Driscoll KE, Leikauf GD. Chemokine regulation of ozone-induced neutrophil and monocyte inflammation. Am J Physiol 1998;274:L39-L46.

3. Arsalane K, Gosset P, Vanhee D, Voisin C, Hamid Q, Tonnel AB, Wallaert B. Ozone stimulates synthesis of inflammatory cytokines by alveolar macrophages in vitro. Am J Respir Cell Mol Biol 1995;13:60-68.

4. Pendino KJ, Shuler RL, Laskin JD, Laskin DL. Enhanced production of interleukin-1, tumor necrosis factor-alpha, and fibronectin by rat lung phagocytes following inhalation of a pulmonary irritant. Am J Respir Cell Mol Biol 1994;11:279-286.

5. Noviski N, Brewer JP, Skornik WA, Galli SJ, Drazen JM, Martin TR. Mast cell activation is not required for induction of airway hyperresponsiveness by ozone in mice. J Appl Physiol 1999;86:202-210.

6. Zhang LY, Levitt RC, Kleeberger SR. Differential susceptibility to ozone-induced airways hyperreactivity in inbred strains of mice. Exp Lung Res 1995;21:503-518.

7. Li Z, Daniel EE, Lane CG, Arnaout MA, O'Byrne PM. Effect of an anti-Mo1 MAb on ozone-induced airway inflammation and airway hyperresponsiveness in dogs. Am J Physiol 1992;263:L723-L726.

8. O'Byrne PM, Walters EH, Gold BD, Aizawa HA, Fabbri LM, Alpert SE, Nadel JA, Holtzman MJ. Neutrophil depletion inhibits airway hyperresponsiveness induced by ozone exposure. Am Rev Respir Dis 1984;130:214-219.

9. Evans TW, Brokaw JJ, Chung KF, Nadel JA, McDonald DM. Ozoneinduced bronchial hyperresponsiveness in the rat is not accompanied by neutrophil influx or increased vascular permeability in the trachea. Am Rev Respir Dis 1988;138:140-144.

10. Holtzman MJ, Fabbri LM, O'Byrne PM, Gold BD, Aizawa H, Walters EH, Alpert SE, Nadel JA. Importance of airway inflammation for hyperresponsiveness induced by ozone. Am Rev Respir Dis 1983;127:686690.

11. Schelegle ES, Siefkin AD, McDonald RJ. Time course of ozone-induced neutrophilia in normal humans. Am Rev Respir Dis 1991;143:1353-1358.

12. Hazucha MJ, Madden M, Pape G, Becker S, Devlin R, Koren HS, Kehrl $\mathrm{H}$, Bromberg PA. Effects of cyclo-oxygenase inhibition on ozoneinduced respiratory inflammation and lung function changes. Eur $J$ Appl Physiol 1996;73:17-27.

13. Watanabe S, Frank R, Yokoyama E. Acute effects of ozone on lungs of cats. I. Functional. Am Rev Respir Dis 1973;108:1141-1151.

14. Kotlikoff MI, Jackson AC, Watson JW. Oscillatory mechanics of the respiratory system in ozone-exposed rats. J Appl Physiol 1984;56:182-186.

15. Cody RP, Weisel CP, Birnbaum G, Lioy PJ. The effect of ozone associated with summertime photochemical smog on the frequency of asthma visits to hospital emergency departments. Environ Res 1992;58:184-194.

16. Weisel CP, Cody RP, Lioy PJ. Relationship between summertime ambient ozone levels and emergency department visits for asthma in central New Jersey. Environ Health Perspect 1995;103(Suppl 2):97-102.

17. Thurston GD, Ito K, Kinney PL, Lippmann M. A multi-year study of air pollution and respiratory hospital admissions in three New York State metropolitan areas: results for 1988 and 1989 summers. J Expo Anal Environ Epidemiol 1992;2:429-450.

18. Rusznak C, Devalia JL, Sapsford RJ, Davies RJ. Ozone-induced mediator release from human bronchial epithelial cells in vitro and the influence of nedocromil sodium. Eur Respir J 1996;9:2298-2305.

19. Kleeberger SR, Levitt RC, Zhang LY, Longphre M, Harkema J, Jedlicka A, Eleff SM, DiSilvestre D, Holroyd KJ. Linkage analysis of susceptibility to ozone-induced lung inflammation in inbred mice. Nat Genet 1997; 17:475-478. 
20. Young C, Bhalla DK. Effects of ozone on the epithelial and inflammatory responses in the airways: role of tumor necrosis factor. $J$ Toxicol Environ Health 1995;46:329-342.

21. Pearson AC, Bhalla DK. Effects of ozone on macrophage adhesion in vitro and epithelial and inflammatory responses in vivo: the role of cytokines. J Toxicol Environ Health 1997;50:143-157.

22. Kips JC, Tavernier J, Pauwels RA. Tumor necrosis factor causes bronchial hyperresponsiveness in rats. Am Rev Respir Dis 1992;145:332-336.

23. Thomas PS, Yates DH, Barnes PJ. Tumor necrosis factor-alpha increases airway responsiveness and sputum neutrophilia in normal human subjects. Am J Respir Crit Care Med 1995;152:76-80.

24. Jagels MA, Daffern PJ, Zuraw BL, Hugli TE. Mechanisms and regulation of polymorphonuclear leukocyte and eosinophil adherence to human airway epithelial cells [In Process Citation]. Am J Respir Cell Mol Biol 1999;21:418-427.

25. Leon LR, Kozak W, Peschon J, Kluger MJ. Exacerbated febrile responses to LPS, but not turpentine, in TNF double receptor-knockout mice. Am J Physiol 1997;22:R563-R569.

26. Peschon JJ, Torrance DS, Stocking KL, Glaccum MB, Otten C, Willis CR, Charrier K, Morrissey PJ, Ware CB, Mohler KM. TNF receptordeficient mice reveal divergent roles for p55 and p75 in several models of inflammation. J Immunol 1998;160:943-952.

27. Ruby J, Bluethmann H, Peschon JJ. Antiviral activity of tumor necrosis factor (TNF) is mediated via p55 and p75 TNF receptors. J Exp Med 1997;186:1591-1596.

28. Pfeffer K, Matsuyama T, Kundig TM, Wakeham A, Kishihara K, Shahinian A, Wiegmann K, Ohashi PS, Kronke M, Mak TW. Mice deficient for the $55 \mathrm{kd}$ tumor necrosis factor receptor are resistant to endotoxic shock, yet succumb to L. monocytogenes infection. Cell 1993; 73:457-467.

29. Thorne PS, Karol MH. Assessment of airway reactivity in guinea pigs: comparison of methods employing whole body plethysmography. Toxicology 1988;52:141-163.

30. Hamelmann E, Schwarze J, Takeda K, Oshiba A, Larsen GL, Irvin CG, Gelfand EW. Noninvasive measurement of airway responsiveness in allergic mice using barometric plethysmography. Am J Respir Crit Care Med 1997; 156:766-775.

31. De Sanctis GT, MacLean JA, Hamada K, Mehta S, Scott JA, Jiao A, Yandava CN, Kobzik L, Wolyniec WW, Fabian AJ, Venugopal CS, Grasemann H, Huang PL, Drazen JM. Contribution of nitric oxide synthases 1, 2, and 3 to airway hyperresponsiveness and inflammation in a murine model of asthma. J Exp Med 1999;189:1621-1630.

32. Tepper JS, Blanchard JD, Pfeiffer JW. Validation of noninvasive measures of bronchoconstriction in mice. Am J Respir Crit Care Med 1997; 155:A160.

33. Drazen JM, Finn PW, De Sanctis GT. Mouse models of airway responsiveness: physiological basis of observed outcomes and analysis of selected examples using these outcome indicators. Annu Rev Physiol 1999;61:593-625.

34. Takebayashi T, Abraham J, Murthy GG, Lilly C, Rodger I, Shore SA. Role of tachykinins in airway responses to ozone in rats. J Appl Physiol 1998;85:442-450.

35. Bascom R, Bromberg PA, Costa DA, Devlin R, Dockery DW, Frampton MW, Lambert W, Samet JM, Speizer FE, Utell M. Health effects of outdoor air pollution. Committee of the Environmental and Occupational Health Assembly of the American Thoracic Society. Am J Respir Crit Care Med 1996;153:3-50.

36. Weister MJ, Williams TB, King E, Menache MG, Muller FJ. Ozone uptake in awake Sprague-Dawley rats. Toxicol Appl Pharmacol 1987;89: 429-437.

37. McDonnell WF, Stewart PW, Andreoni S, Seal E Jr, Kehrl HR, Horstman DH, Folinsbee LJ, Smith MV. Prediction of ozone-induced FEV1 changes. Effects of concentration, duration, and ventilation. Am J Respir Crit Care Med 1997;156:715-722.

38. Kleeberger SL ZL-Y, Jedlicka AE, Keen, JC. Ozone $\left(\mathrm{O}_{3}\right)$-induced inflammation is mediated via 55 and $75 \mathrm{kDa}$ receptors for tumor necrosis factor- $\alpha(\mathrm{TNF} \alpha)$ in mice. Am J Respir Crit Care Med 1999;159:A24.

39. Longphre M, Zhang L, Harkema JR, Kleeberger SR. Ozone-induced pulmonary inflammation and epithelial proliferation are partially mediated by PAF. J Appl Physiol 1999;86:341-349.

40. Kleeberger SR, Levitt RC, Zhang LY. Susceptibility to ozone-induced inflammation. II. Separate loci control responses to acute and subacute exposures. Am J Physiol 1993;264:L21-L26.

41. Zheng L, Fisher G, Miller RE, Peschon J, Lynch DH, Lenardo MJ. Induction of apoptosis in mature T cells by tumour necrosis factor. $\mathrm{Na}$ ture 1995;377:348-351.

42. Tartaglia LA, Goeddel DV, Reynolds C, Figari IS, Weber RF, Fendly BM, Palladino MA Jr. Stimulation of human T-cell proliferation by specific activation of the $75-\mathrm{kD}$ a tumor necrosis factor receptor. $J$ Immunol 1993;151:4637-4641.

43. Wang B, Fujisawa H, Zhuang L, Kondo S, Shivji GM, Kim CS, Mak TW, Sauder DN. Depressed Langerhans cell migration and reduced contact hypersensitivity response in mice lacking TNF-receptor p75. J Immunol 1997;159:6148-6155.

44. Lucas R, Juillard P, Decoster E, Redard M, Burger D, Donati Y, Giroud C, Monso-Hinard C, De Kesel T, Buurman WA, Moore MW, Dayer JM, Fiers W, Bluethmann H, Grau GE. Crucial role of tumor necrosis factor (TNF) receptor 2 and membrane-bound TNF in experimental cerebral malaria. Eur J Immunol 1997;27:1719-1725.

45. Sheehan KC, Pinckard JK, Arthur CD, Dehner LP, Goeddel DV, Schreiber RD. Monoclonal antibodies specific for murine p55 and p75 tumor necrosis factor receptors: identification of a novel in vivo role for p75. J Exp Med 1995;181:607-617.

46. Amrani Y, Panettieri RA Jr, Frossard N, Bronner C. Activation of the TNF alpha-p55 receptor induces myocyte proliferation and modulates agonist-evoked calcium transients in cultured human tracheal smooth muscle cells. Am J Respir Cell Mol Biol 1996;15:55-63.

47. Jimba M, Skornik WA, Killingsworth CR, Long NC, Brain JD, Shore SA. Role of C fibers in physiological responses to ozone in rats. J Appl Physiol 1995;78:1757-1763.

48. Mautz WJ, Bufalino C. Breathing pattern and metabolic rate responses of rats exposed to ozone. Respir Physiol 1989;76:69-77.

49. Tepper JS, Wiester MJ, Weber MF, Menache MG. Measurements of cardiopulmonary response in awake rats during acute exposure to near-ambient concentrations of ozone. J Appl Toxicol 1990;10:7-15.

50. Slade R, Watkinson WP, Hatch GE. Mouse strain differences in ozone dosimetry and body temperature changes. Am J Physiol 1997;272: L73-L77. 